\title{
Metazoan parasites on the gills of the skipjack tuna Katsuwonus pelamis (Osteichthyes: Scombridae) from the Alboran Sea (western Mediterranean Sea)
}

\author{
Salvatore Mele ${ }^{1,2, *}$, David Macías ${ }^{3}$, María J. Gómez-Vives ${ }^{3}$, Giovanni Garippa ${ }^{1}$, \\ Francisco Alemany ${ }^{2}$, Paolo Merella ${ }^{1}$
}

\footnotetext{
${ }^{1}$ Sezione di Parassitologia e Malattie Parassitarie, Dipartimento di Biologia Animale, Università di Sassari, 07100 Sassari, Italy

${ }^{2}$ Instituto Español de Oceanografía, Centre Oceanogràfic de les Balears, 07015 Palma, Spain

${ }^{3}$ Instituto Español de Oceanografía, Centro Oceanográfico de Málaga, 29640 Fuengirola (Málaga), Spain
}

\begin{abstract}
The gills of 31 skipjack tuna Katsuwonus pelamis (L.) caught in the Alboran Sea (western Mediterranean Sea) were examined for metazoan parasites, and the gills of 4 specimens from the Balearic Sea (also western Mediterranean Sea) were analysed for comparative purposes. Nine species of parasites were found, including 8 didymozoid trematodes (Atalostrophion cf. biovarium, Didymocylindrus filiformis, Didymocylindrus simplex, Didymocystis reniformis, Didymoproblema fusiforme, Didymozoon longicolle, Koellikeria sp. and Lobatozoum multisacculatum) and 1 caligid copepod (Caligus bonito). Koellikeria sp. and L. multisacculatum were not recorded in the Balearic Sea. Most of the parasites (79.2\% of all specimens) were didymozoids. Didymozoon longicolle was the dominant species; $A$. cf. biovarium, $D$. simplex, $D$. fusiforme and $L$. multisacculatum are reported from the Mediterranean Sea for the first time. No correlation was found between the intensity of infection of any parasite species and host size or sex. Most of the parasites, particularly didymozoids, showed a high site-specificity. Significant differences were found between the parasite assemblages of K. pelamis from the Alboran Sea and from the Atlantic Ocean. D. fusiforme, D. longicolle and L. multisacculatum are suggested as potential tags to follow skipjack tuna migrations between the Atlantic Ocean and Mediterranean Sea.
\end{abstract}

KEY WORDS: Katsuwonus pelamis · Didymozoidae $\cdot$ Caligidae $\cdot$ Gill parasites $\cdot$ Biological tags Site specificity $\cdot$ Mediterranean Sea

Resale or republication not permitted without written consent of the publisher

\section{INTRODUCTION}

The skipjack tuna Katsuwonus pelamis (Linnaeus, 1758; Osteichthyes: Scombridae) is an opportunistic predator that inhabits the tropical and warm temperate waters of all oceans (Collette \& Nauen 1983). The range of this fish in the Atlantic Ocean is from $40^{\circ} \mathrm{N}$ to $32^{\circ} \mathrm{S}$, from the surface to about $260 \mathrm{~m}$ depth. Its distribution is influenced by water temperature (optimum range from 15 to $30^{\circ} \mathrm{C}_{i}$ Evans et al. 1981). The skipjack tuna spawns when the surface temperature is $\geq 24^{\circ} \mathrm{C}$, and its spawning season varies according to locality (Cayré \& Farrugio 1986).
In the eastern Atlantic Ocean, this tuna spawns year round in the equatorial area from the Gulf of Guinea to $20-30^{\circ} \mathrm{W}$, while it spawns only in the warm season in the tropical area. In the Mediterranean Sea the skipjack tuna has been traditionally considered occasional (Postel 1963), but Macías et al. (2010) reported its presence in the western Mediterranean Sea throughout the summer, where it seems also capable of spawning (Alemany et al. 2010). In the western Atlantic Ocean, this tuna spawns in 2 main subtropical areas off the coast of South America, and its migration is influenced by season (Andrade \& Santos 2004). 
The skipjack tuna fishery is the fourth largest in the world (2.4 million $t$ in 2008, 1.4 million $t$ of which is from the Atlantic Ocean, and 80 t from the Mediterranean Sea; FAO 2010). The International Commission for the Conservation of Atlantic Tunas (ICCAT) manages this fishery, dividing it into western and eastern (including Mediterranean Sea) stocks, with the boundary at $30^{\circ} \mathrm{W}$ (ICCAT 2006).

Despite the great economic importance of this fish and the several studies that have been undertaken with respect to the species worldwide, little is known about its biology or migrations in the Mediterranean Sea (Di Natale et al. 2009).

In several fish species, parasites have been used successfully to examine differences between host populations and to study migration patterns (Lester 1990, MacKenzie \& Abaunza 1998, Lester \& MacKenzie 2009). Nakamura \& Yuen (1961) studied the distribution of the digenean Hirudinella ventricosa (Pallas, 1774) in the Pacific skipjack tuna, showing differences among fish caught from different areas. Watertor (1973) found variations in the distribution of H. ventricosa in skipjack tuna from Brazil, Florida and West Africa. The gill parasites of tunas are often used as biological tags, because gills are not affected by handling, can be easily dissected during evisceration and do not have any commercial value (Rodríguez-Marín et al. 2008, Mele et al. 2010a). The parasite assemblage of the gill of Katsuwonus pelamis varies between the Indo-Pacific and the Atlantic Oceans (Lester et al. 1985, Alves \& Luque 2006), and is dominated by didymozoids (Skrjabin 1955, Lester et al. 1985), but also includes monogeneans and copepods (Bussiéras \& Baudin-Laurencin 1973, Cressey \& Cressey 1980, Alves \& Luque 2006).

The aim of the present study was to investigate the metazoan gill parasites of the skipjack tuna from the Alboran Sea (western Mediterranean) and to evaluate their possible use as biological tags.

\section{MATERIALS AND METHODS}

Between July and September 2008, 31 skipjack tuna caught by trolling in the Alboran Sea (in an area extending from 36.01 to $36.09^{\circ} \mathrm{N}$, and from 4.40 to $4.60^{\circ} \mathrm{W}$ ) were examined for parasites. Immediately after landing, fish were measured, weighed and sexed (fork-length range from 57.5 to $68.0 \mathrm{~cm}$; totalweight range from 4.2 to $6.4 \mathrm{~kg} ; 14$ males and 17 females). Four other specimens of skipjack tuna (2 males and 2 females) caught off the island of Majorca (Balearic Sea, western Mediterranean Sea; area

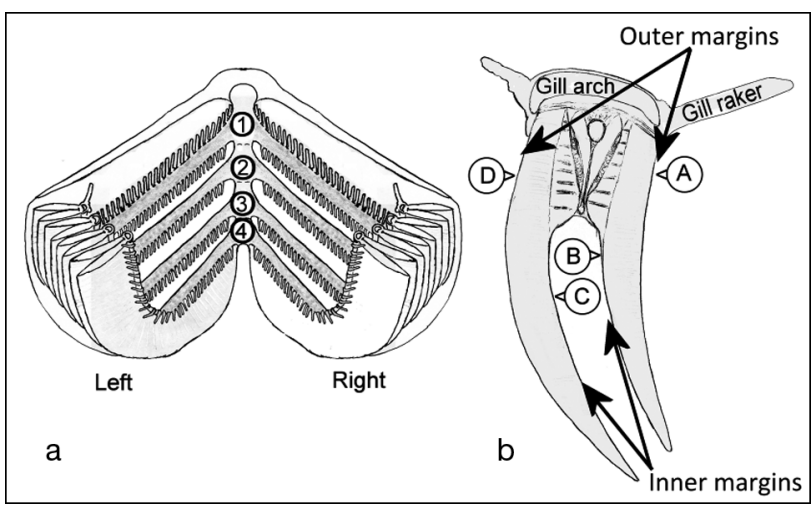

Fig. 1. Katsuwonus pelamis. Potential microhabitats on gills showing (a) holobranchs $(1,2,3,4)$ on both sides, (b) margins of gill filaments, in transverse section, from external $(A, D)$ to internal $(B, C)$

extending from 38.9 to $39.7^{\circ} \mathrm{N}$, and from 2.4 to $3.6^{\circ} \mathrm{E}$ ) were examined for comparative purposes. Fork length of these specimens ranged from 58.0 to $66.5 \mathrm{~cm}$ and total weight from 4.0 to $6.3 \mathrm{~kg}$.

The gills of all specimens were excised, stored individually in plastic bags and frozen at $-20^{\circ} \mathrm{C}$.

In the laboratory, the gills were defrosted and examined under a stereo microscope for metazoan parasites. Location of the parasites was recorded according to Mele et al. (2010a; Fig. 1): holobranchs were numbered from 1 to 4 (from the anteriorexternal to the posterior-internal), and their surfaces labelled from A to D. All parasites were counted and stored in $70 \%$ ethanol. For microscopic analysis and species identification, parasites were prepared according to standard protocols (Cribb \& Bray 2010). Fresh and mounted parasites were micrographed and measured with a digital system connected to a microscope and stereomicroscope. References used for species identification included, for didymozoids, Ishii (1935), Skrjabin (1955) and Pozdnyakov \& Gibson (2008), and, for copepods, Cressey \& Cressey (1980) and Kabata (1992).

Prevalence (percentage of infected hosts, $\mathrm{P} \%$ ) and mean intensity (mean number of parasites per infected host, mI) of infection of each parasite species were calculated according to Bush et al. (1997). CI of prevalence and mean intensity were calculated with Sterne's exact method and the Efron-Tibshirani bootstrap, respectively, and their differences evaluated with Fisher's exact test and bootstrap test, respectively, using Quantitative Parasitology 3.0 software (Reiczigel \& Rózsa 2005). Levels of infection were calculated according to sex and location on the host. To evaluate possible correlations between the host size and intensity of infection, Spearman's rank cor- 
relation coefficient was tested with Student's $t$-test (Zar 1996). Results were compared with data previously published; dominance (proportional abundance of the most abundant species) was calculated with the Berger-Parker index (d) (Maguran 2004); community similarity was evaluated using Jaccard (J) and Sørensen (QS) indices (Magurran 2004).

Voucher material (nos. SKJ2008.0002-0511) was deposited in the collection of the Sezione di Parassitologia e Malattie Parassitarie, Dipartimento di Biologia Animale, Università di Sassari.

\section{RESULTS}

Nine species of parasites (didymozoids and copepods) were found on the gills of the 31 skipjack tuna from the Alboran Sea (Table 1). All the fish examined were infected by at least one parasite species.
Most of the parasites (79.2\% of all specimens) were adult didymozoids, represented by Atalostrophion cf. biovarium, Didymocylindrus filiformis, Didymocylindrus simplex, Didymocystis reniformis, Didymoproblema fusiforme, Didymozoon longicolle, Koellikeria sp., and Lobatozoum multisacculatum. Copepods $(20.8 \%$ of all specimens) were represented only by the caligid Caligus bonito (chalimi and adults). D. longicolle was the dominant species ( $d=0.64)$, showing the highest prevalence and mean intensity $(\mathrm{P} \%=94 \%, \mathrm{mI}=9.2)$, followed by $C$. bonito $(\mathrm{P} \%=77 \%, \mathrm{mI}=3.6)$. No significant differences of prevalence and mean intensity were found between host sexes, and no significant correlation was found between intensity of infection and host size. The parasites of the 4 specimens caught off Majorca are given in Table 1; Koellikeria sp. and $L$. multisacculatum were not recorded in the Balearic Sea samples.

Table 1. Katsuwonus pelamis. Parasite species found on gills. P\%: prevalence (\%); mI: mean intensity; Alb: Alboran Sea; Bal: Balearic Sea; SwA: south-western Atlantic Ocean (Justo \& Kohn 2005, Alves \& Luque 2006); Car: Caribbean Sea (Lester et al. 1985); CeA: central-eastern Atlantic Ocean (Cissé et al. 2007); +: present (qualitative data); $95 \%$ CI in parentheses (-: no CI). ${ }^{*}$ Statistically significant difference between regions $(\mathrm{p}<0.05)$

\begin{tabular}{|c|c|c|c|c|c|c|c|c|}
\hline \multirow[t]{2}{*}{ Parasite species } & \multicolumn{2}{|l|}{ Alb } & \multicolumn{2}{|c|}{ Bal } & \multicolumn{2}{|c|}{ SwA } & \multirow[t]{2}{*}{ Car } & \multirow[t]{2}{*}{$\mathrm{CeA}$} \\
\hline & $\mathrm{P} \%$ & $\mathrm{mI}$ & $\mathrm{P} \%$ & $\mathrm{mI}$ & $\mathrm{P} \%$ & $\mathrm{mI}$ & & \\
\hline \multicolumn{9}{|l|}{ Monogeneans } \\
\hline $\begin{array}{l}\text { Allopseudaxine macrova } \\
\text { (Unnithan, 1957) }\end{array}$ & $0(0-11)^{*}$ & 0.0 & $0(0-53)$ & 0.0 & $27^{*}$ & 1.5 & & + \\
\hline Capsalidae gen. sp. & $0(0-11)^{*}$ & 0.0 & $0(0-53)$ & 0.0 & $13^{*}$ & 1.0 & & \\
\hline \multicolumn{9}{|l|}{ Didymozoids } \\
\hline $\begin{array}{l}\text { Atalostrophion cf. biovarium } \\
\text { Skrjabin, } 1955\end{array}$ & $16(7-34)$ & $2(1.4-3.2)$ & $50(10-90)$ & $1.5(1.0-1.5)$ & 0 & 0.0 & & \\
\hline $\begin{array}{l}\text { Diplotrema pelamydis } \\
\text { Yamaguti, } 1938\end{array}$ & $0(0-11)$ & 0.0 & $0(0-53)$ & 0.0 & 13 & 1.0 & & \\
\hline $\begin{array}{l}\text { Didymocylindrus filiformis } \\
\text { Ishii, } 1935\end{array}$ & $10(3-26)$ & $1.7(1.0-2.3)$ & $50(10-90)$ & $5.0(-)$ & 0 & 0.0 & + & \\
\hline $\begin{array}{l}\text { Didymocylindrus simplex } \\
\text { (Ishii, 1935) }\end{array}$ & $26(13-44)^{*}$ & $3.1(1.9-5.0)$ & $50(10-90)$ & $3.0(2.0-3.0)$ & $0^{*}$ & 0.0 & + & \\
\hline $\begin{array}{l}\text { Didymocystis reniformis } \\
\text { Ariola, } 1902\end{array}$ & $7(1-30)$ & $1.0(-)$ & $25(1-75)$ & $1.0(-)$ & 0 & 0.0 & & \\
\hline $\begin{array}{l}\text { Didymoproblema fusiforme } \\
\text { Ishii, } 1935\end{array}$ & $29(16-47)$ & $1.8(1.2-2.2)$ & $25(1-75)$ & $11.0(-)$ & 38 & 6.3 & + & \\
\hline Didymozoon sp. & $0(0-11)$ & 0.0 & $0(0-53)$ & 0.0 & 27 & 5.3 & & \\
\hline $\begin{array}{l}\text { Didymozoon longicolle } \\
\text { Ishii, } 1935\end{array}$ & $94(79-99)^{*}$ & $9.2(6.7-13.6)$ & 75 (25-99) & $8.0(1.0-12.3)$ & $0^{*}$ & 0.0 & & \\
\hline Koellikeria sp. & $3(0-17)$ & $1.0(-)$ & $0(0-53)$ & 0.0 & 0 & 0.0 & & \\
\hline $\begin{array}{l}\text { Lobatozoum multisacculatum } \\
\text { Ishii, } 1935\end{array}$ & $3(0-17)$ & $1.0(-)$ & $0(0-53)$ & 0.0 & 13 & 2.5 & & \\
\hline \multicolumn{9}{|l|}{ Copepods } \\
\hline $\begin{array}{l}\text { Caligus bonito Wilson, } 1905 \\
\text { (adult and chalimus) }\end{array}$ & $77(60-89)$ & $3.6(2.7-5.0)$ & $25(1-75)$ & $2.0(-)$ & 80 & 3.9 & & \\
\hline Caligus pelamydis Krøyer, 1863 & $0(0-11)$ & 0.0 & $0(0-53)$ & 0.0 & 0 & 0.0 & & + \\
\hline Caligus productus Dana, 1852 & $0(0-11)$ & 0.0 & $0(0-53)$ & 0.0 & 13 & 2.5 & + & \\
\hline $\begin{array}{l}\text { Pseudocycnus appendiculatus } \\
\text { Heller, } 1865\end{array}$ & $0(0-11)$ & 0.0 & $0(0-53)$ & 0.0 & 13 & 1.0 & & \\
\hline
\end{tabular}


Table 2. Katsuwonus pelamis. Sørensen (below diagonal) and Jaccard (above diagonal) indices of similarity for assemblages of metazoan parasites on gills of specimens from different localities. See Table 1 for locality abbreviations

\begin{tabular}{|lcccc|}
\hline & Alb & SwA & Car & CeA \\
\hline Alb & - & 0.20 & 0.44 & 0.00 \\
SwA & 0.33 & - & 0.18 & 0.10 \\
Car & 0.62 & 0.31 & - & 0.00 \\
CeA & 0.00 & 0.18 & 0.00 & - \\
\hline
\end{tabular}

A comparison of the levels of infection of fish from the Alboran Sea with data from the south-western Atlantic Ocean (Justo \& Kohn 2005, Alves \& Luque 2006 ) is shown in Table 1. This table also shows qualitative data from the Caribbean Sea (Lester et al. 1985) and the central-eastern Atlantic Ocean (Cissé et al. 2007). Mediterranean (including both the Alboran and Balearic Seas) and south-western Atlantic hosts showed a higher number of species than the other Atlantic areas. Allopseudoaxine macrova (Unnithan, 1957) and Capsalidae gen. sp. (found only in the Atlantic Ocean), Didymocylindrus simplex (found mainly in the Mediterranean Sea) and Didymozoon longicolle (found only in the Mediterranean Sea) showed significant differences of prevalence between the Alboran Sea and the south-western Atlantic Ocean.

Analysis of similarity showed that the Alboran gill parasite community more closely resembled the Caribbean community $(\mathrm{J}=0.44$; QS $=0.62)$ than the south-western $(\mathrm{J}=0.20$ and $\mathrm{QS}=0.33)$ or centraleastern Atlantic $(\mathrm{J}=0.00$ and $\mathrm{QS}=0.00$; Table 2$)$ communities.

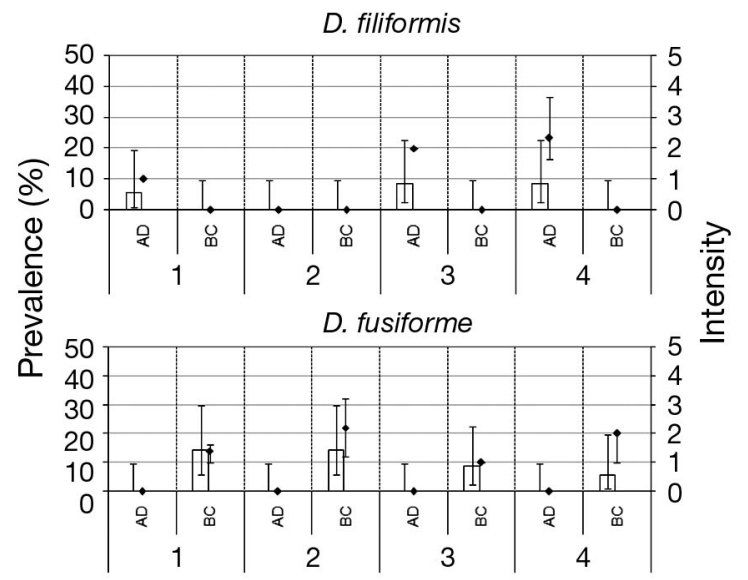

No significant differences in $\mathrm{P} \%$ or $\mathrm{mI}$ were observed between left and right gills. Fig. 2 shows the distribution of the didymozoids on the gill filaments. Atalostrophion cf. biovarium was found in the connective tissue near the blood vessels of the gill arches. Didymocylindrus filiformis was encysted in the proximal part of the outer margins of holobranch gill filaments (not found in the second one), with significant difference in $\mathrm{mI}$ between the first and third holobranchs. Didymocylindrus simplex was found in the first third of the outer sides. Didymocystis reniformis and Koellikeria sp. were located on the gill arches. Didymoproblema fusiforme formed cysts hanging by a filiform process attached to the base of the free portion of the inner margins of the gill filament. Didymozoon longicolle was encysted in the first third of the inner margins of the gill filaments, and its prevalence was significantly higher in the first and second holobranchs. Lobatozoum multisacculatum was found in the middle third of the outer margins of gill filaments. Chalimi of Caligus bonito were attached by their frontal filaments to the base of the gill rakers of the first and second holobranchs, with significantly higher prevalence on the first one, while adults were found on the gill filaments, with significantly higher prevalence on the outer margins (A and $\mathrm{D}_{i}$ Fig. 1) of the second holobranch.

\section{DISCUSSION}

The metazoan parasite fauna on the gills of the skipjack tuna from the Atlantic Ocean and Mediterranean Sea includes a total of 16 species or other

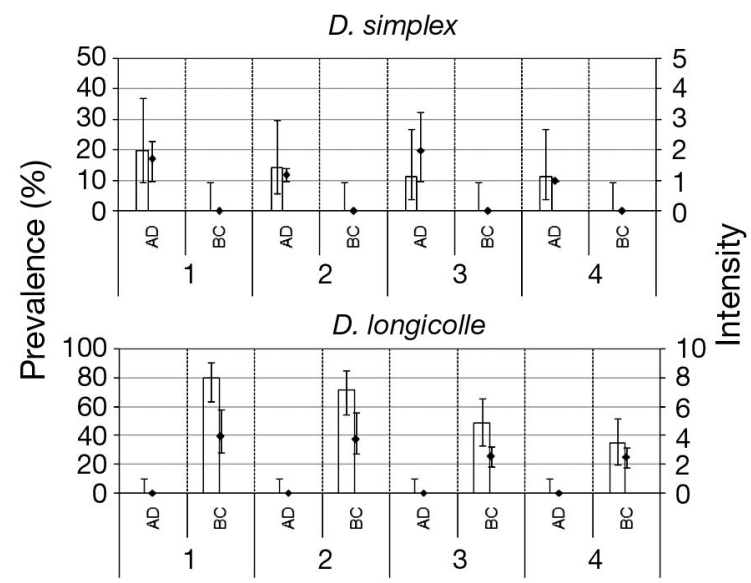

Fig. 2. Prevalence (\%) and mean intensity $( \pm \mathrm{CI})$ of didymozoid parasites on gill filaments of skipjack tuna Katsuwonus pelamis. Histogram bar: prevalence; : mean intensity. Letters on $x$-axis refer to location on gill filament margins, as in Fig. 1 
taxa. Among them, Atalostrophion cf. biovarium, Diplotrema pelamydis and Didymocylindrus simplex may be considered specialists, being reported only in this host (Skrjabin 1955, Lester et al. 1985, Justo \& Kohn 2005). Most of the parasites of the skipjack tuna show a wide geographical range, being found from the equator to the temperate latitudes of the Atlantic and Pacific Oceans, and they infect more than one host species: Didymocylindrus filiformis has been reported in Pacific Katsuwonus pelamis and Thunnus orientalis (Ishii 1935), in Caribbean K. pelamis (Lester et al. 1985) and in Mediterranean Thunnus thynnus (Mladineo et al. 2008). The copepods Caligus bonito, C. pelamydis and Pseudocycnus appendiculatus have been found in several scombrids from all oceans (Cressey \& Cressey 1980). Other parasites are limited to the tropical regions. Allopseudaxine macrova has been found in some fish from tropical areas of the Pacific and Indian Oceans, and from the central-eastern and south-western Atlantic Ocean (Bussiéras \& BaudinLaurencin 1973, Mogrovejo et al. 2004). Bussiéras \& Baudin-Laurencin (1973) collected many specimens of Didymozoidae, belonging to the genera Didymozoon, Koellikeria, Didymocystis, Nematobothrium and Lobatozoum, from 4 tuna species (including $K$. pelamis) from the central-eastern Atlantic Ocean. Didymoproblema fusiforme has been recorded in Pacific K. pelamis and Thunnus orientalis (Ishii 1935) and south-western Atlantic K. pelamis (Justo \& Kohn 2005). Lobatozoum multisacculatum has been found in Pacific K. pelamis and T. orientalis (Ishii 1935) and in south-western Atlantic Euthynnus alletteratus and K. pelamis (Alves \& Luque 2006). Caligus productus has been found in several tropical scombrids from all oceans (Cressey \& Cressey 1980). Other species seem to have a more narrow range. Didymocystis reniformis has been found only in $T$. thynnus from the Mediterranean Sea (Culurgioni et al. 2007) and in Thunnus alalunga from the Gulf of Biscay (Dollfus 1952); K. pelamis is a new host for this parasite. Didymozoon longicolle has been reported in several scombrids from the Pacific Ocean (Ishii 1935), but in the Atlantic area it has been collected only in T. thynnus and T. alalunga from the Mediterranean Sea (Mladineo et al. 2008, Mele et al. 2010a,b), and in Thunnus albacares from the Gulf of Mexico (Nikolaeva \& Parukhin 1968).

This study is the first contribution to knowledge of the gill metazoan parasites of Katsuwonus pelamis from the Mediterranean Sea; this is also the first time that Atalostrophion cf. biovarium, Didymocylindrus simplex, Didymoproblema fusiforme and Lobatozoum multisacculatum have been reported from the
Mediterranean Sea. Most of the gill parasites of $K$. pelamis from the Alboran Sea are didymozoids, with Didymozoon longicolle as dominant species. A clear dominance of didymozoids was also observed in Thunnus alalunga (Jones 1991, Mele et al. 2010a), T. albacares (Lardeaux 1982) and $T$. thynnus (Rodríguez-Marín et al. 2008), suggesting that tunas are among the preferred hosts for didymozoids (Nikolaeva 1985). The parasite assemblage from the Alboran Sea seems to be more similar to that of the Caribbean Sea than those of other Atlantic areas, but the results may be somewhat biased by the fact that the number of samples from the tropical areas has been small (particularly from the Caribbean Sea and central-eastern Atlantic Ocean). D. fusiforme and $L$. multisacculatum, the only 2 didymozoids found in both Alboran and south-western Atlantic skipjack tuna, showed similar values of prevalence in both localities. This may be due to the occurrence of these parasites only in the tropical Atlantic areas (centraleastern and south-western Atlantic Ocean) and their presence in tuna from the Alboran Sea only after host migration; this hypothesis is supported by the record of these parasites in other tropical tunas (Bussiéras \& Baudin-Laurencin 1973, Justo \& Kohn 2005, Alves \& Luque 2006) and their absence in any other Mediterranean host (Dollfus 1926, Mladineo et al. 2008, Mele et al. 2010b). The significant differences in prevalence of $D$. simplex and $D$. longicolle (recorded only in Alboran hosts) and Allopseudoaxine macrova and Capsalidae gen. sp. (only in south-western Atlantic hosts) suggest that the presence or absence of these species is characteristic of each locality. However, the presence of unidentified Didymozoon sp. in both the central-eastern and south-western Atlantic Ocean (Bussiéras \& Baudin-Laurencin 1973, Alves \& Luque 2006) suggests caution, because these parasites may also belong to the species $D$. longicolle. The absence of $A$. macrova and Capsalidae gen. sp. in skipjack tuna from the Alboran Sea could be due to their loss when tuna migrate from the area where these parasites are endemic (i.e. tropical areas of the Atlantic Ocean) to the higher latitudes, where the parasites may find the conditions unsuitable (MacKenzie \& Abaunza 1998).

Because the size of fish sampled from the Alboran Sea and the south-western Atlantic Ocean (Lester et al. 1985, Alves \& Luque 2006) is similar, size should not to be considered as having explained the differences between areas.

The parasites on the gills of Katsuwonus pelamis from the western Mediterranean Sea show a high site specificity, particularly with regard to didymo- 
zoids; in fact, these parasites occupy almost every microhabitat available on this organ, without niche overlapping between species. Most of the didymozoids were found encapsulated, except Atalostrophion cf. biovarium, which was found free in gill connective tissue. These differences in site specificity may be due to different feeding and egg-release strategies, developed during phylogenetic evolution (Lester 1980, Mladineo et al. 2010). Caligus bonito also shows site specificity on the gills of the skipjack tuna; according to Lo \& Morand (2001), the significant differences in locations between adults and chalimi of $C$. bonito reflect different ecological requirements.

Didymozoids, in spite of their complex systematics, difficulty of identification and the lack of information regarding their life cycles, have often been proposed as tags (e.g. Lester et al. 1985, Oliva et al. 2008, Mele et al. 2010a, Mladineo et al. 2010). In fact, these parasites can remain recognizable in host tissues for a long time (permanent to semipermanent parasites, sensu Lester et al. 1985). They also have a marked sitespecificity that facilitates detection and species identification (Rohde 2002) and cause few pathological alterations (Mladineo 2006). Lester et al. (1985) observed differences in the parasite assemblages of the skipjack tuna, considering the gill parasites Didymocylindrus filiformis, D. simplex, Didymoproblema fusiforme and Lobatozoum multisacculatum as possible tags to show the trophic migration from tropical water to New Zealand, and to distinguish one area's skipjack tuna populations from those of another area. The record of $D$. fusiforme and L. multisacculatum in the Alboran Sea supports the hypothesis of migration of skipjack tuna from the Atlantic Ocean into the Mediterranean Sea, as assumed by the current stock management strategy (ICCAT 2006). Moreover, the absence of significant differences between the prevalence of $D$. fusiforme and L. multisacculatum between tropical and Alboran samples suggests that the lifespan of these parasites could be longer than the duration of the host migration. The high P\% and $\mathrm{mI}$ of Didymozoon longicolle in Katsuwonus pelamis from the Alboran Sea, which is also found in other Mediterranean tunas (Mladineo et al. 2008, Mele et al. 2010b) and in Thunnus albacares from the Gulf of Mexico (Nikolaeva \& Parukhin 1968), suggests that this didymozoid could be useful for following the specimens of K. pelamis that leave these areas. Nevertheless, the location of $D$. longicolle (inside the gill tissue) makes its detection difficult, perhaps explaining the lack of attention to it in some studies. Monogeneans and caligids should be considered carefully as tags, because they are easily dislodged during dissection, they have a short lifespan, and the host can lose them when migrating to areas with conditions unsuitable for the parasites.

Acknowledgements. We thank the fishermen of the Club de Mar de Puerto Banús, of the Club Nàutic S'Estanyol and of the Federació Balear de Pesca i Casting for their collaboration during the sampling, We benefited from the advice and support of J. Bruno, D. Díaz, N. Díaz, L. González, A. Pérez, P. Reglero and C. Vignolo. Our research was partially supported by Assessorato Difesa Ambiente RAS No. 32688-4930.12.08 Fondazione Banco di Sardegna 2010, and the project GPM-3 (Grandes Pelágicos del Mediterráneo) of the Instituto Español de Oceanografia.

\section{LITERATURE CITED}

Alemany F, Quintanilla L, Velez-Belchi P, García A and others (2010) Characterization of the spawning habitat of Atlantic bluefin tuna and related species in the Balearic Sea (western Mediterranean). Prog Oceanogr 86:21-38

Alves DR, Luque JL (2006) Ecologia das comunidades de metazoários parasitos de cinco espécies de escombrídeos (Perciformes: Scombridae) do litoral do estado do Rio de Janeiro, Brasil. Rev Bras Parasitol 15:167-181

Andrade HA, Santos JAT (2004) Seasonal trends in the recruitment of skipjack tuna (Katsuwonus pelamis) to the fishing ground in the southwest Atlantic. Fish Res 66: 185-194

> Bush AO, Lafferty KD, Lotz JM, Shostak AW (1997) Parasitology meets ecology on its own terms: Margolis et al. revisited. J Parasitol 83:575-583

Bussiéras J, Baudin-Laurencin F (1973) Les helminthes parasites des thons tropicaux. Rev Elev Med Vet Pays Trop 26(4):13a-19a

Cayré P, Farrugio H (1986) Biologie de la reproduction du listao (Katsuwonus pelamis) de l'Océan Atlantique. In: Symons PEK, Miyake PM, Sakagawa GT (eds) Proc ICCAT Conf Int Skipjack Yr Prog Publications, Madrid, p 252-272

Cissé M, Bédé O, Gourène G, Ouattara A, Gnayoro M (2007) Helminth and copepod parasites of skipjack tuna Katsuwonus pelamis (Pisces, Scombridae) disembarked at the harbour of Abidjan (Atlantic coast of Ivory Coast). Proc 7th Int Symp Fish Parasites. Parassitologia 49(Suppl 2):243

Collette BB, Nauen CE (1983) FAO species catalogue, Vol. 2: scombrids of the world. FAO Fish Synop 125:1-137

Cressey R, Cressey HB (1980) Parasitic copepods of mackerel and tuna-like fishes (Scombridae) of the world. Smithson Contrib Zool 311:1-186

Cribb TH, Bray RA (2010) Gut wash, body soak, blender and heat-fixation: approaches to the effective collection, fixation and preservation of trematodes of fishes. Syst Parasitol 76:1-7

Culurgioni J, Merella P, Addis P, Cau A, Figus V, Mele S, Garippa G (2007) Metazoan gill parasites of wild Atlantic bluefin tuna Thunnus thynnus (L.) caught off Sardinia (western Mediterranean). Proc 7th Int Symp Fish Parasites. Parassitologia 49(Suppl 2):244

Di Natale A, Srour A, Hattour A, Keskin Ç, Idrissi M, Orsi Relini L (2009) Regional study on small tunas in the Mediterranean including the Black Sea. Studies and Reviews, No. 85. FAO, Rome 
Dollfus RP (1926) Sur l'état actuel de la classification des Didymozoonidae Monticelli, 1888 (Didymozoidae Franz Poche, 1907). Ann Parasitol Hum Comp 4:148-161

Dollfus RP (1952) Parasites du Germo alalunga (J. F. Gmelin 1788). ICES J Mar Sci 18:42-44

Evans RH, McLain DR, Bauer RA (1981) Atlantic skipjack tuna: influences of mean environmental conditions on their vulnerability to surface fishing gear. Mar Fish Rev 43: $1-11$

FAO (Food and Agriculture Organization) (2010) FishStat Plus: universal software for fishery statistical time series, 2.3.2000, available at http://www.fao.org/fishery/statistics/software/fishstat/en

ICCAT (International Commission for the Conservation of Atlantic Tunas) (2006) Skipjack tuna. ICCAT Manual, 2006-2009. ICCAT Publications, p 53-74, available at http://www.iccat.int/en/ICCATManual.htm

Ishii N (1935) Studies on the family Didimozoidae (Monticelli, 1888). Jap J Zool 6:279-335

Jones JB (1991) Movements of albacore tuna (Thunnus alalunga) in the South Pacific: evidence from parasites. Mar Biol 111:1-9

Justo MCN, Kohn A (2005) Didymozoidae (Digenea) parasites of Scombridae (Actinopterygii) from Rio de Janeiro coast, Brazil. Rev Bras Zoociênc 7:333-338

Kabata Z (1992) Copepods parasitic on fishes: keys and notes for identification of species. In: Kermack DM, Barnes RSK, Crothers JH (eds) Synopses of the British fauna (new series), No. 47. The Linnean Society of London

Lardeaux F (1982) Etude de la structure des populations d'albacores (Thunnus albacares) dans l'Atlantique tropical par l'analyse des chiffres d'infestations parasitaire. Col Sci Pap ICCAT 17:68-74

Lester RJG (1980) Host-parasite relationships in some didymozoid trematodes. J Parasitol 66:527-531

Lester RJG (1990) Reappraisal of the use of parasites for fish stock identification. Aust J Mar Freshw Res 41:855-864

- Lester RJG, MacKenzie K (2009) The use and abuse of parasites as stock markers for fish. Fish Res 97:1-2

Lester RJG, Barnes A, Habib G (1985) Parasites of skipjack tuna, Katsuwonus pelamis: fishery implications. Fish Bull (US) 83:343-356

Lo CM, Morand S (2001) Gill parasites of Cephalopholis argus (Teleostei: Serranidae) from Moorea (French Polynesia): site selection and coexistence. Folia Parasitol 48:30-36

Macías D, Gómez-Vives MJ, Benjumea ME, Saber S, Godoy D, Báez JC (2010) Catch rates of albacore (Thunnus alalunga) from the Spanish recreational fishery in the Balearic Sea (Mediterranean Sea), 2004-2009. Col Sci Pap ICCAT 65:1456-1460

MacKenzie K, Abaunza P (1998) Parasites as biological tags for stock discrimination of marine fish: a guide to procedures and methods. Fish Res 38:45-56

Magurran AE (2004) Measuring biological diversity. Blackwell Publishing, Oxford

Mele S, Merella P, Macías D, Gómez MJ, Garippa G, Alemany F (2010a) Metazoan gill parasites of wild albacore Thunnus alalunga (Bonaterre, 1788) from the Balearic Sea (western Mediterranean) and their use as biological tags. Fish Res 102:305-310

Mele S, Garippa G, Macías D, Gómez MJ, Alemany F, Merella P (2010b) Didymozoid trematodes on gills of four

Editorial responsibility: Sven Klimpel,

Frankfurt am Main, Germany tuna species (Osteichthyes: Scombridae: Thunnini) from the western Mediterranean Sea. Proc 26th Congresso nazionale della Società Italiana di Parassitologia. Perugia, 22-25 giugno 2010. Parassitologia 52:358

Mladineo I (2006) Histopathology of five species of Didymocystis spp. (Digenea: Didymozoidae) in cage-reared Atlantic bluefin tuna (Thunnus thynnus thynnus). Vet Res Commun 30:475-484

- Mladineo I, Žilic J, ankovi M (2008) Health survey of Atlantic bluefin tuna, Thunnus thynnus (Linnaeus, 1758), reared in Adriatic cages from 2003 to 2006. J World Aquacult Soc 39: 281-289

> Mladineo I, Bott NJ, Nowak BF, Block BA (2010) Multilocus phylogenetic analyses reveal that habitat selection drives the speciation of Didymozoidae (Digenea) parasitizing Pacific and Atlantic bluefin tunas. Parasitology 137: 1013-1025

Mogrovejo C, Lent H, Santos C (2004) Morphological aspects of marine monogeneans (Platyhelminthes) parasitic on the gills of Auxis thazard (Lacépède) (Scombridae) from Rio de Janeiro, Brazil. Rev Bras Zool 21:201-206

> Nakamura EL, Yuen HSH (1961) Incidence of the giant trematode, Hirudinella marina Garcin, in skipjack tuna, Euthynnus pelamis (Linnaeus), from Marquesan and Hawaiian waters. Trans Am Fish Soc 90:419-423

Nikolaeva VM (1985) Trematodes: Didymozoidae fauna, distribution and biology. In: Hargis WJ (ed) Parasitology and pathology of marine organisms of the world ocean. NOAA Tech Rep NMFS 25. National Oceanic and Atmospheric Administration, Washington, DC, p 67-72

Nikolaeva VM, Parukhin AM (1968) The study of fish helminths in the Gulf of Mexico. Mater Sov Kubin Morsk Eksped 2:126-149 (in Russian)

Oliva ME, Valdivia IM, Costa G, Freitas N, Pinheiro De Carvalho MA, Sánchez ZL, Luque JL (2008) What can metazoan parasites reveal about the taxonomy of Scomber japonicus Houttuyn in the coast of South America and Madeira Islands? J Fish Biol 72:545-554

Postel E (1963) Exposé synoptique des données biologiques sur la bonite â ventre rayé Katsuwonus pelamis (Linné, 1758). FAO Fish Rep 2:515-537

Pozdnyakov SE, Gibson DI (2008) Family Didymozoidae Monticelli, 1888. In: Bray RA, Gibson DI, Jones A (eds) Keys to the Trematoda, Vol 3. CABI, Wallingford, p 631-734

Reiczigel J, Rózsa L (2005) Quantitative parasitology 3.0. Budapest, available at http://www.zoologia.hu/qp/qp. html

> Rodríguez-Marín E, Barreiro S, Montero FE, Carbonell E (2008) Looking for skin and gill parasites as biological tags for Atlantic bluefin tuna (Thunnus thynnus). Aquat Living Resour 21:365-371

Rohde K (2002) Niche restriction and mate finding in vertebrate hosts. In: Lewis EE, Campbell JF, Sukhdeo MVK (eds) The behavioural ecology of parasites. CABI, Wallingford, p 171-198

Skrjabin KI (1955) Suborder Didymozoata Skjrabin et Schulz, 1937. Osnovy Trematodologii 11:5-254 (in Russian)

Watertor JL (1973) Incidence of Hirudinella marina Garcin, 1730 (Trematoda: Hirudinellidae) in tunas from the Atlantic Ocean. J Parasitol 59:207-208

Zar JH (1996) Biostatistical analysis, 3rd edn. Prentice-Hall, Upper Saddle River, NJ

Submitted: July 25, 2011; Accepted: October 24, 2011

Proofs received from author(s): December 17, 2011 